\title{
Identifikasi Kandungan Kimia Pada Pasir Sungai Brantas
}

\author{
Ah. Sulhan Fauzi ${ }^{1)}$, Kuni Nadliroh'2). \\ ${ }^{1,2)}$ Teknik Mesin, Universitas Nusantara PGRI Kediri Jl. Mojoroto, Kediri, Indonesia \\ E-mail: ${ }^{1)}$ sulhanfauzi@unpkediri.ac.id, ${ }^{2)}$ kuninadliroh@ unpkediri.ac.id
}

\begin{abstract}
Abstrak
Daerah aliran sungai Brantas yang panjang tentunya memiliki potensi pasir yang melimpah. Namun pemanfaatan pasir sungai Brantas masih terbatas hanya sebagai bahan bangunan. Padahal banyak sekali unsur kimia pada pasir sungai yang bisa dimanfaatkan. Penelitian ini bertujuan untuk mengetahui atau mengidentifikasi kandungan unsur kimia yang terkandung dalam pasir sungai Brantas. Penelitian ini dilakukan dengan mengekstraksi sampel pasir besi dari pasir Sungai Brantas menggunakan magnet kemudian diidentifikasi melalui uji XRD dan SEM. Hasil XRD menunjukkan kandungan Kalsium Aluminium Silikat (Al2CaO8Si2), magnetit (Fe3O4), Magnesium Vanadium Oksida (Mg0,966 (V1,64Mg0,36) Mg0,105O4) dan Sodium Zinc Iron Phosphorus Oxide (Na (Zn0,8Fe0,2 ) PO4).
\end{abstract}

Kata Kunci: : pasir sungai, unsur kimia, ekstraksi, XRD, SEM.

Abstract
The long watershed of the Brantas river certainly has the abundant potential of sand. However, the utilization of Brantas's river sand is still limited only as a building materials. Even though there are a lot of chemical elements at a river sand that can be used. This study aims to determine or identify the content of chemical elements contained in sand from the Brantas river. This research was conducted by extracting iron sand samples from the Brantas River sand using a magnet and then identified through XRD and SEM tests. XRD results show the content of Calcium Aluminum Silicate $\left(\mathrm{Al}_{2} \mathrm{CaO}_{8} \mathrm{Si}_{2}\right)$, magnetite $\left(\mathrm{Fe}_{3} \mathrm{O}_{4}\right)$, Magnesium Vanadium Oxide $\left(\mathrm{Mg}_{0,966}\right.$ $\left.\left(\mathrm{V}_{1,64} \mathrm{Mg}_{0,36}\right) \mathrm{Mg}_{0,105} \mathrm{O}_{4}\right)$ and Sodium Zinc Iron Phosphorus Oxide $\left(\mathrm{Na}\left(\mathrm{Zn}_{0,8} \mathrm{Fe}_{0,2}\right) \mathrm{PO}_{4}\right)$.

Keywords: river sand, chemical elements, extraction, XRD, SEM

\section{PENDAHULUAN}

Potensi sumber daya alam Indonesia sangat melimpah. Salah satunya adalah pasir dari sungai. Selama ini pasir dari sungai diambil oleh warga sekitar untuk dijual sebagai bahan bangunan dengan harga yang relatif murah, atau sebagai bahan tambahan pada pabrik semen [1]. Padahal, banyak sekali kegunaan pasir sungai, misalnya dapat digunakan sebagai sumber calsite oxide $\left(\mathrm{CaCO}_{3}\right)$ dan quartz oxide $\left(\mathrm{SiO}_{2}\right)$ [2]. Pasir dari sungai juga dapat digunakan untuk penyerapan gelombang mikro karena mengandung oksida besi $\left(\mathrm{Fe}_{2} \mathrm{O}_{3}\right.$ dan $\left.\mathrm{Fe}_{3} \mathrm{O}_{4}\right)$ dan silika oksida $\left(\mathrm{SiO}_{2}\right)$ serta senyawa lain seperti Fe, Ni dan Zn dengan kandungan yang kecil [3, 4]. 
Badan Energi dan Sumber Daya Mineral Jawa Timur [5] mencatat bahwa di Jawa Timur terdapat sumber batu gamping, emas, perak, tembaga, andesit, marmer, ball clay, belerang, pasir dan bahan mineral lainnya yang belum terekstraksi sepenuhnya. Badan ESDM Jawa Timur juga mencatat adanya cadangan pasir di daerah aliran sungai Lumajang dengan luas sekitar 60 ribu hektar dan di sungai Brantas sekitar 32 ribu hektar. Pasir dari Lumajang memiliki kandungan besi yang tinggi, rata-rata 30 sampai 40 persen, bahkan ada yang sampai 60 persen.

Tujuan dari penelitian ini adalah untuk mengetahui dan mengidentifikasi kandungan pasir sungai brantas. Selama ini penelitian pasir selalu mengambil sampel pasir dari sungai-sungai yang ada di daerah Lumajang [7, 8].

Penelitian ini dilakukan dalam dua tahap, yaitu tahap lapangan dan tahap laboratorium. Tahap lapangan adalah pengambilan sampel pasir di sekitar daerah aliran sungai Brantas. Sedangkan tahapan laboratorium meliputi persiapan sampel pasir, ekstraksi pasir dan karakterisasi hasil ekstraksi dengan melakukan uji material. Kemudian dilakukan analisis komposisi fasa untuk mengetahui kandungan zat-zat di dalamnya. Analisis ini dilakukan setelah material didifraksikan dengan sinar-x dengan X-Rays Diffraction (XRD) untuk identifikasi kristal dan fasa, Scanning Electron Microscope (SEM) untuk identifikasi struktur dan ukuran material.

Untuk mengetahui informasi lebih lanjut tentang bahan yang diuji, dapat dilakukan analisis kuantitatif dengan data difraksi sinar-x yang didasarkan pada kenyataan bahwa intensitas pola difraksi suatu fase dalam campuran tergantung pada konsentrasi fase sampel. Analisis kuantitatif dapat dilakukan secara fisik atau kimia.

Analisis menggunakan difraksi sinar-x adalah teknik yang lebih baik untuk analisis campuran, karena memungkinkan identifikasi berbagai pola difraksi superposisi. Ini karena setiap komponen campuran menghasilkan pola karakteristik yang independen satu sama lain [9]. Analisis kualitatif digunakan untuk menentukan fase apa yang ada dalam suatu material, biasanya disebut identifikasi fase. Berdasarkan hasil pola difraksi dapat dilihat puncak-puncak difraksi dari fasa yang terbentuk, sehingga dapat diperkirakan apakah terdapat fasa kristal atau fasa amorf. 
Analisis kualitatif ini dilakukan untuk menentukan fasa yang tepat yang terbentuk dari bahan yang diuji. Proses tahap Identifikasi didasarkan pada pencocokan data posisi yang diukur dengan database, misalnya menggunakan kartu PDF (Powder Diffraction File).

Identifikasi fase dapat dilakukan dengan menggunakan perangkat lunak yang harus dilakukan dengan hati-hati agar hasil yang diperoleh benar-benar dapat menggambarkan sampel [10]. Langkah-langkah identifikasi menggunakan perangkat lunak terdiri dari: Peak Search (mencari posisi puncak) dan Search Match (mencari posisi puncak dan mencocokkan fase ke database).

\section{METODE PENELITIAN}

a. Persiapan Bahan

Pasir untuk penelitian ini diambil dari dua lokasi di sekitar sungai Brantas di kota Kediri. Sampel pertama diambil di aliran sungai sekitar Kecamatan MojorotoKota Kediri dan sampel kedua diambil dari aliran sungai sekitar Kecamatan MojoKabupaten Kediri. Kedua lokasi berjarak sekitar 17 km. Pasir yang diambil dari sungai Brantas disaring menggunakan saringan plastik untuk memisahkan pasir dan kerikil serta menghilangkan kotoran-kotorannya. Hasil penyaringan, diekstraksi untuk memisahkan unsur pasir dan pasir besi menggunakan magnet sebanyak lima kali.

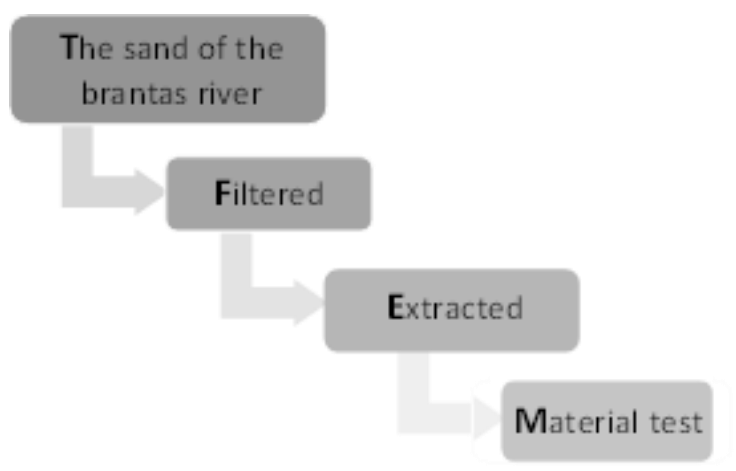

Gambar 1. Diagram Alir Penelitian

b. Uji Bahan

Uji XRD dilakukan untuk melihat fasa-fasa yang terdapat pada bahan. Selanjutnya dilakukan SEM untuk mengetahui bentuk kristal dari sampel. Data yang diperoleh dari SEM dapat digunakan untuk mengetahui material apa saja yang terkandung dalam pasir sungai. 


\section{HASIL DAN PEMBAHASAN}

Secara fisik, kedua sampel tersebut terlihat sedikit berbeda warna. Sampel pertama sedikit lebih gelap dari sampel kedua, seperti yang ditunjukkan pada Gambar 2 dan 3.

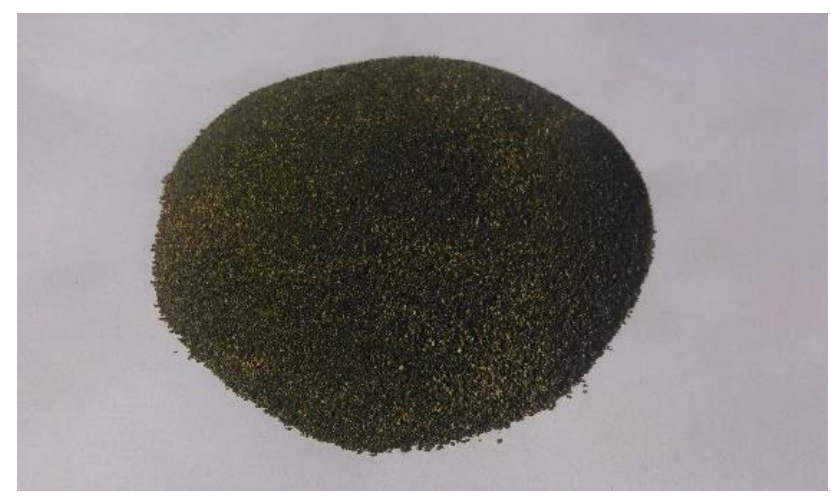

Gambar 2. Pasir dari lokasi pertama

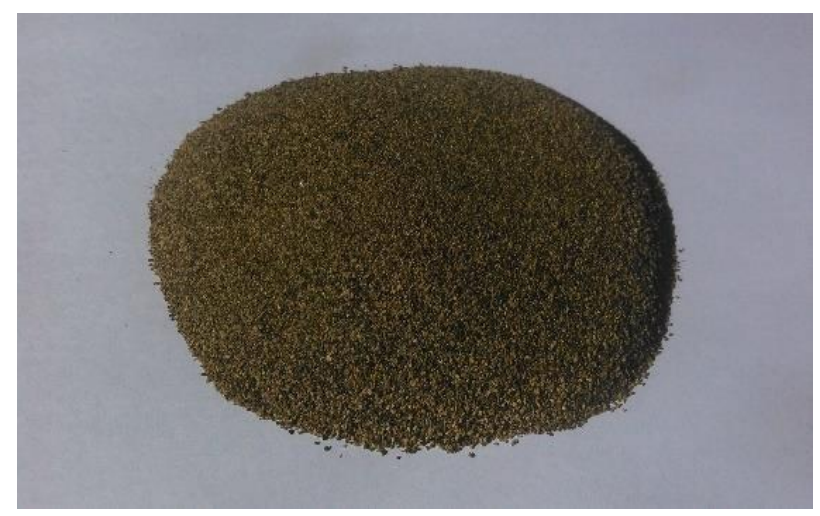

Gambar 3. Pasir dari lokasi pertama

a. Uji XRD

Uji XRD dilakukan untuk mengidentifikasi fasa dari pasir yang diekstraksi dari sungai Brantas. Untuk sampel pertama, hasil XRD menunjukkan pasir Sungai Brantas mengandung 92\% Kalsium Aluminium Silikat $\left(\mathrm{Al}_{2} \mathrm{CaO}_{8} \mathrm{Si}_{2}\right)$. Sedangkan sisanya $8 \%$ adalah Magnetite $\left(\mathrm{Fe}_{3} \mathrm{O}_{4}\right)$, seperti terlihat pada grafik pada Gambar 4 . 


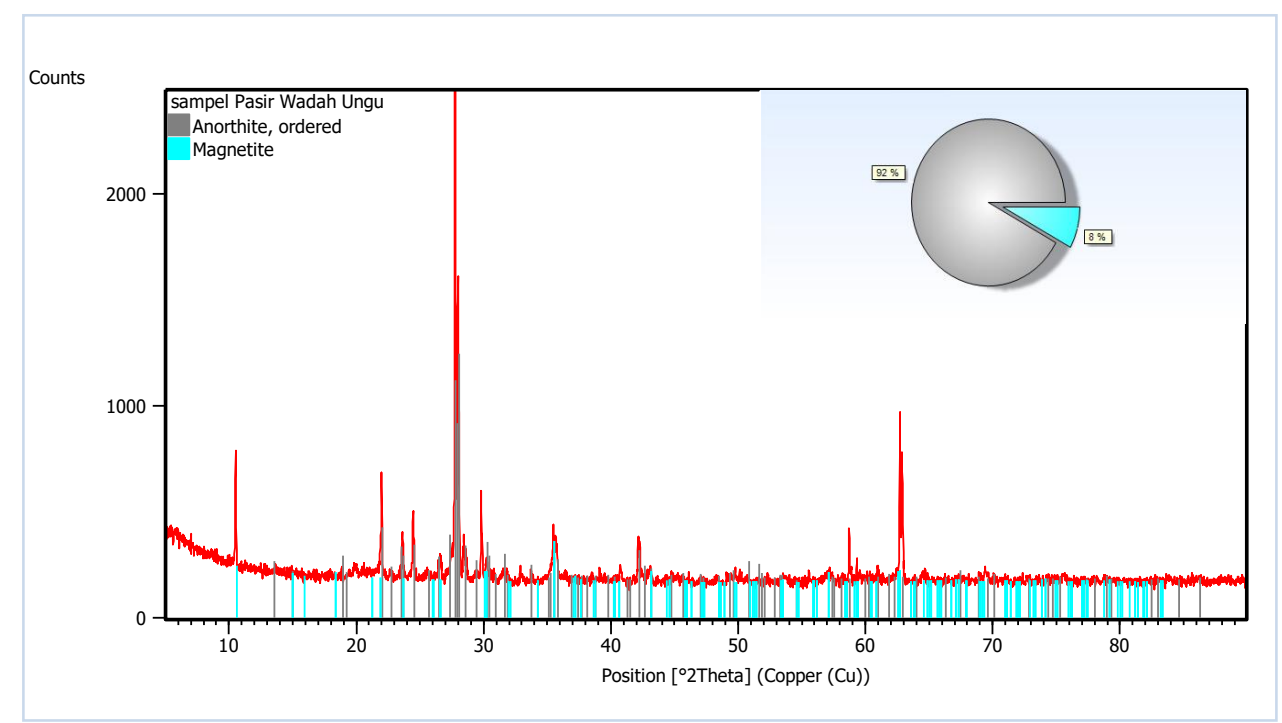

Gambar 4. Pola XRD pasir pada sampel pertama

Setelah melakukan analisis kualitatif terhadap data XRD menggunakan software Match!, diketahui bahwa puncak difraksi XRD kompatibel dengan fase anorthite atau Kalsium Aluminium Silikat $\left(\mathrm{Al}_{2} \mathrm{CaO}_{8} \mathrm{Si}_{2}\right)$ dengan kode PDF 00-041-1486, dengan intensitas tinggi pada sudut difraksi $21,981^{\circ} ; 27.782^{\circ} ; 27.892^{\circ}$; dan puncak intensitas tertinggi pada sudut $28.031^{\circ}$ seperti yang ditunjukkan pada Gambar 5. Untuk fasa lainnya, intensitasnya cukup tinggi pada sudut $2 \Theta 18.319^{\circ} ; 30,057^{\circ}$; $43.077^{\circ} ; 57,037^{\circ} ; 62,68^{\circ}$.

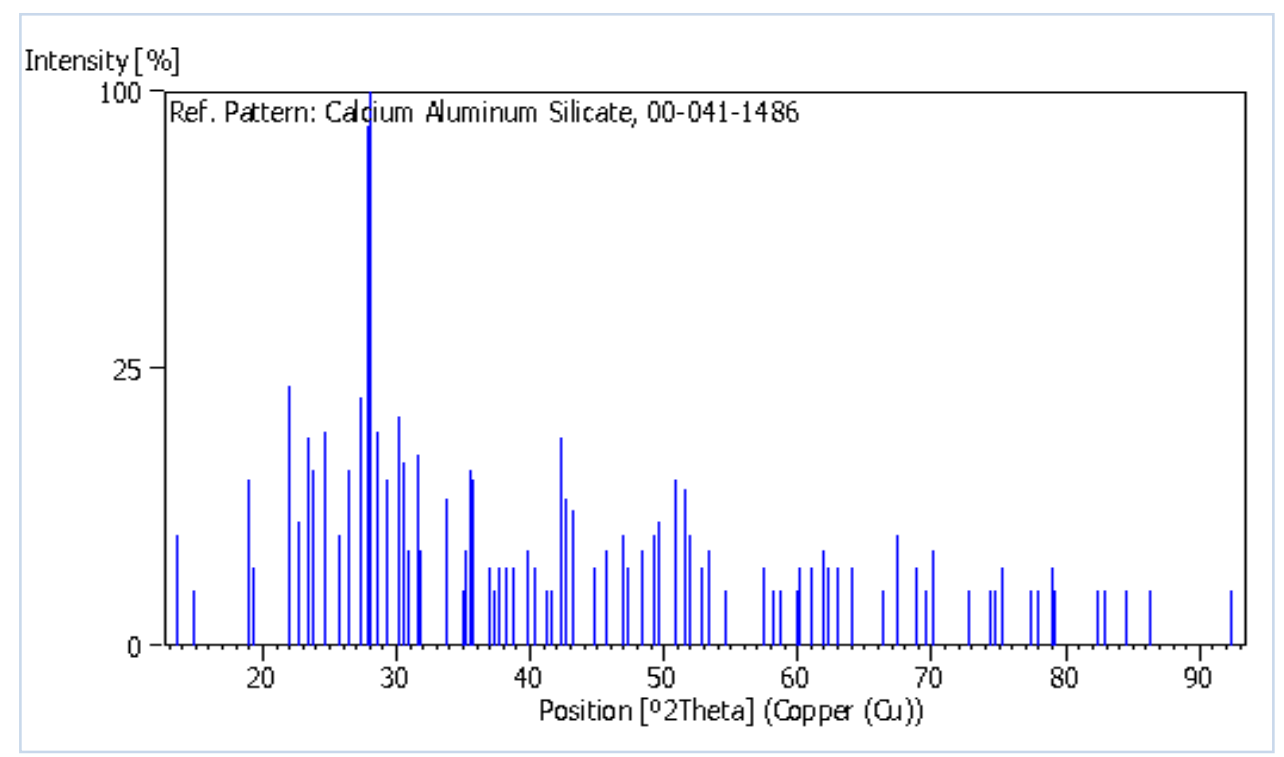

Gambar 5. Identifikasi fase anorthite $\left(\mathrm{CaAl}_{2} \mathrm{Si}_{2} \mathrm{O}_{8}\right)$ untuk pada sampel pertama 
Intensitas tertinggi terjadi pada sudut $35.475^{\circ}$ yang sesuai dengan fase magnetit dengan kode PDF 01-078-3149 seperti yang ditunjukkan pada Gambar 6. Hal ini sesuai dengan hasil penelitian sebelumnya, bahwa salah satu karakteristik magnetit fase adalah bahwa ia memiliki puncak intensitas difraksi tertinggi pada sudut difraksi $2 \Theta 35^{\circ}[11,12]$.

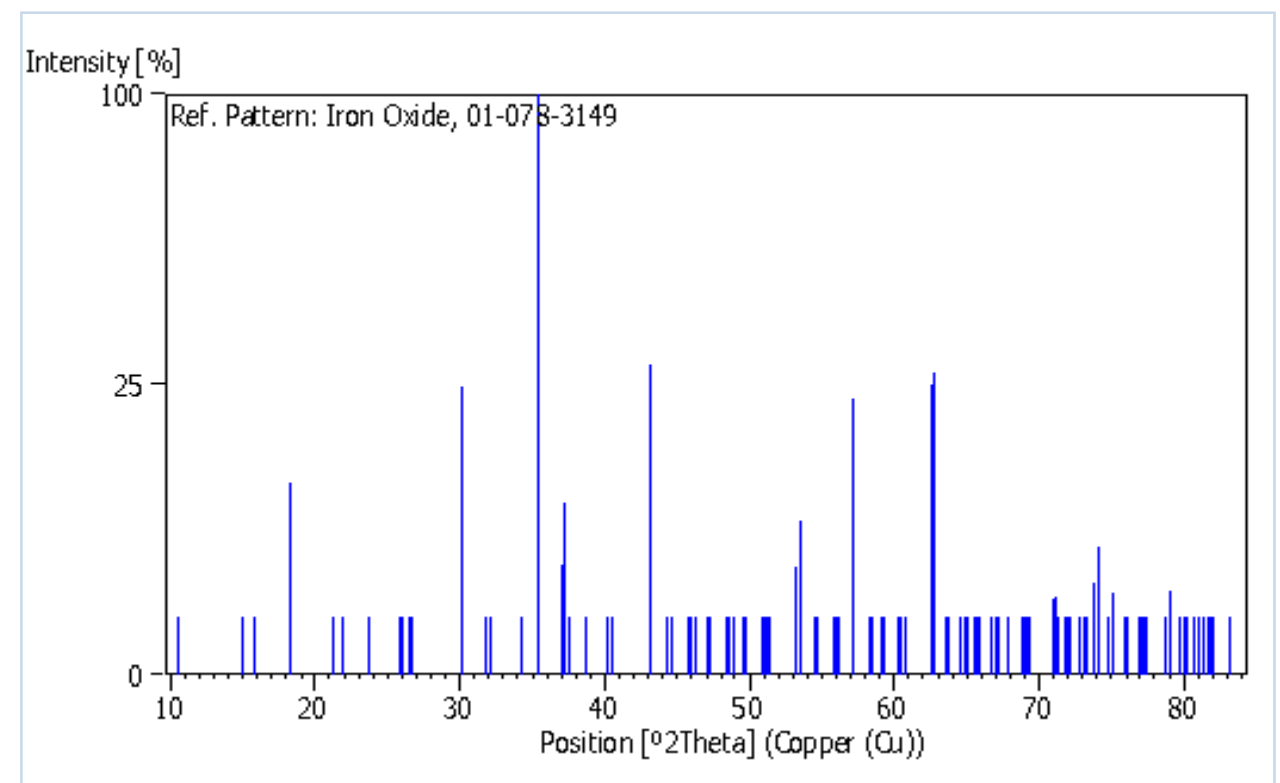

Gambar 6. Identifikasi fase magnetit $\left(\mathrm{Fe}_{3} \mathrm{O}_{4}\right)$ pada sampel pertama

Pada sampel kedua, hasil XRD menunjukkan adanya Magnesium Vanadium Oksida (Mg0.966(V1.64Mg0.36) Mg0.105O4) sebanyak 57\% dan sisanya Natrium Seng Besi Fosfor Oksida (Na (Zn0.8Fe0.2)PO4), seperti yang ditunjukkan pada Gambar 7.

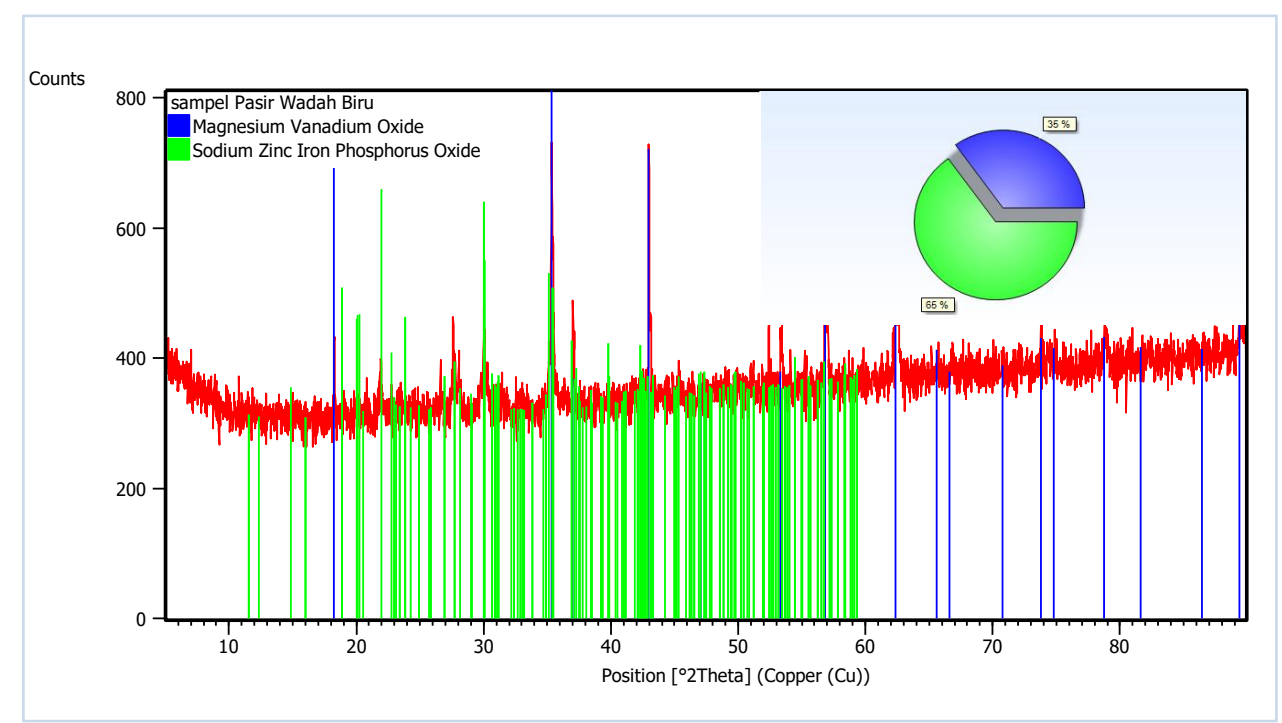

Gambar 7. Pola XRD pada sampel kedua 
Hasil analisis kualitatif data XRD sampel kedua menggunakan software Match!, diketahui bahwa data puncak difraksi hasil XRD sesuai dengan fasa Magnesium Vanadium Oksida dengan kode PDF 01-075-9238, dengan intensitas yang cukup tinggi pada sudut $2 \Theta 18,241^{\circ} ; 42.948^{\circ} ; 56,791^{\circ} ; 62,357^{\circ}$; dan intensitas puncak difraksi terjadi pada sudut $2 \Theta 35,340^{\circ}$ seperti yang ditunjukkan pada Gambar 8 .

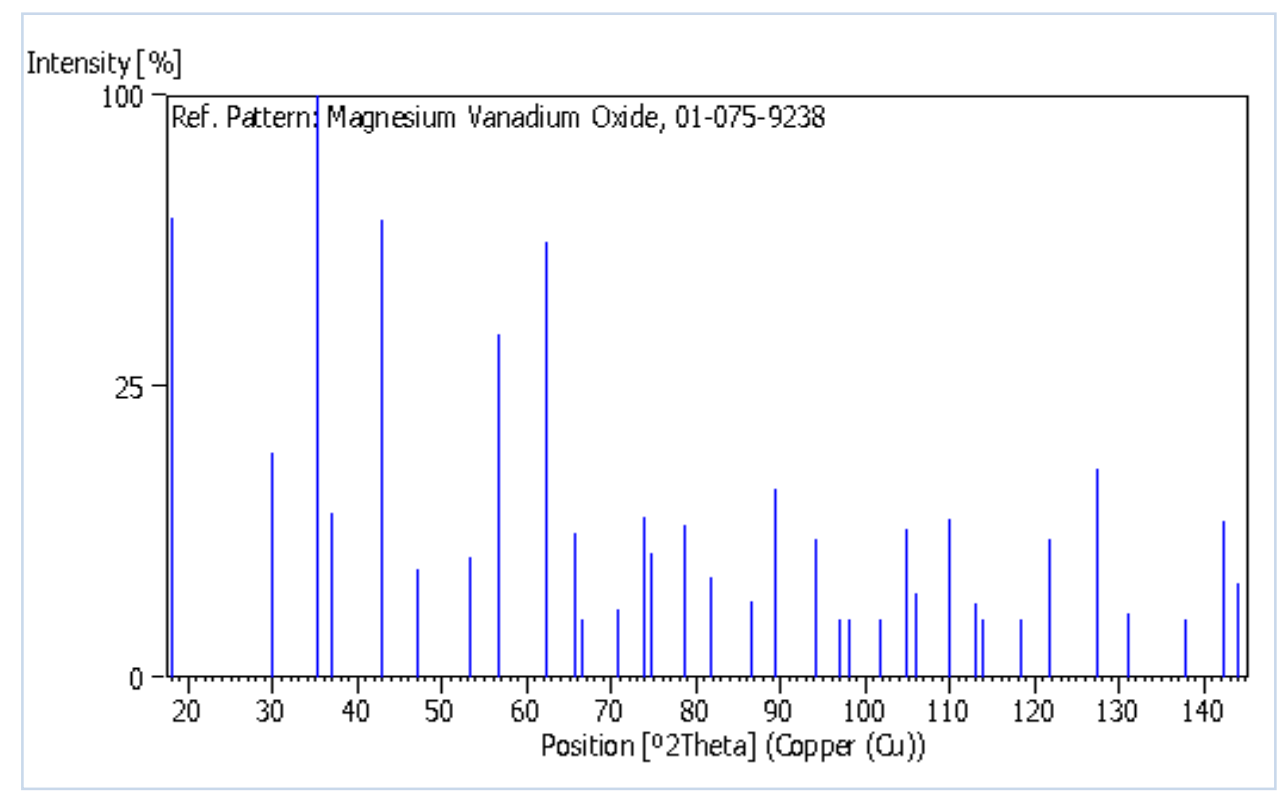

Gambar 8. Identifikasi Magnesium Vanadium Oxide pada sampel kedua

Sedangkan untuk fasa Natrium Seng Besi Fosfor Oksida, intensitas difraksi terjadi pada sudut $18,951^{\circ} ; 20.220^{\circ} ; 22.850^{\circ} ; 23,941^{\circ} ; 30.118^{\circ} ; 30214^{\circ} ; 35.243^{\circ}$; $35.605^{\circ} ; 36.985^{\circ}$; dan puncak intensitas difraksinya terlihat pada sudut $2 \Theta 22.086^{\circ}$ seperti terlihat pada Gambar 9. 


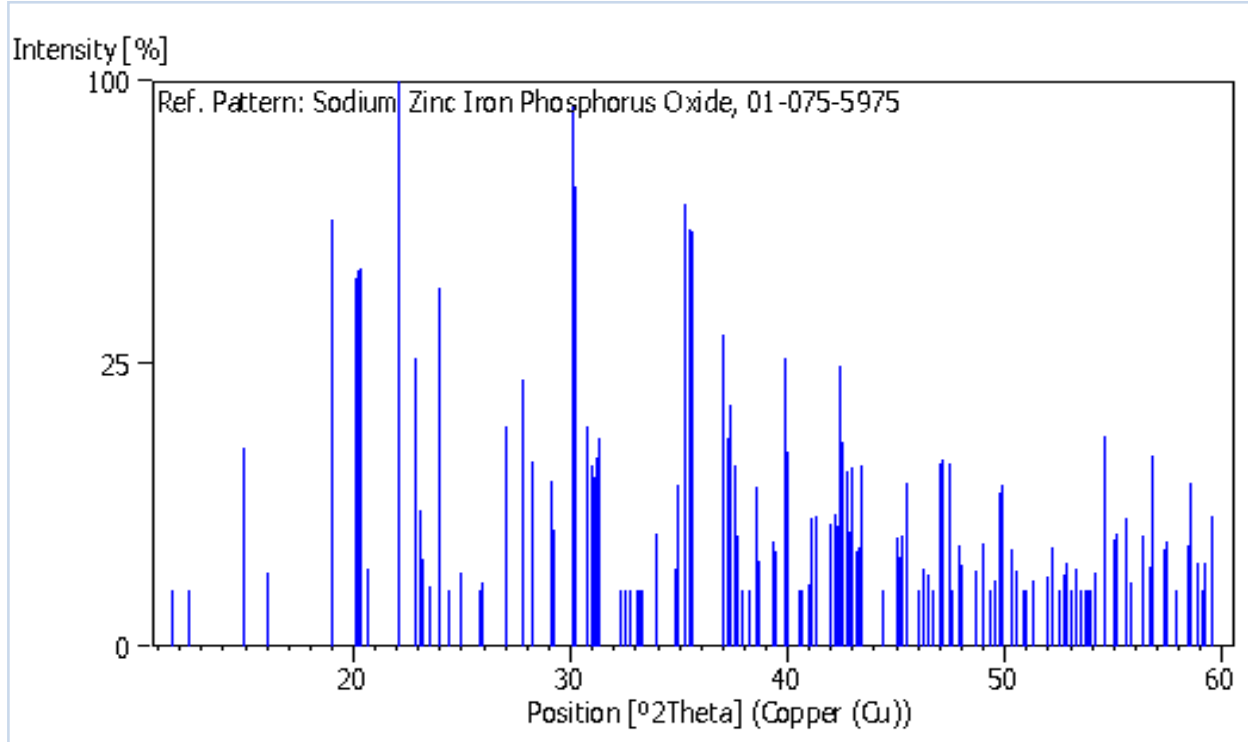

Gambar 9. Identifikasi Sodium Zinc Iron Phosphorus Oxide pada sampel kedua

\section{b. Uji Mikrostruktur}

Foto SEM kedua sampel menunjukkan ukuran butir sampel yang relatif besar yaitu sekitar $0,1 \mathrm{~mm}$, sehingga masih sulit untuk menentukan karakteristik struktur mikronya. Bentuk kristal magnetit kubik, Dari Gambar 10 dan 11 dapat dilihat bahwa beberapa partikel pasir berbentuk kubik, meskipun tidak sempurna. Hal ini dikarenakan sampel tidak diolah dengan perlakuan kimia apapun, hanya pencucian, penyaringan dan ekstraksi menggunakan magnet permanen saja. Hal ini memungkinkan masih terdapat banyak bahan-bahan lainnya. 


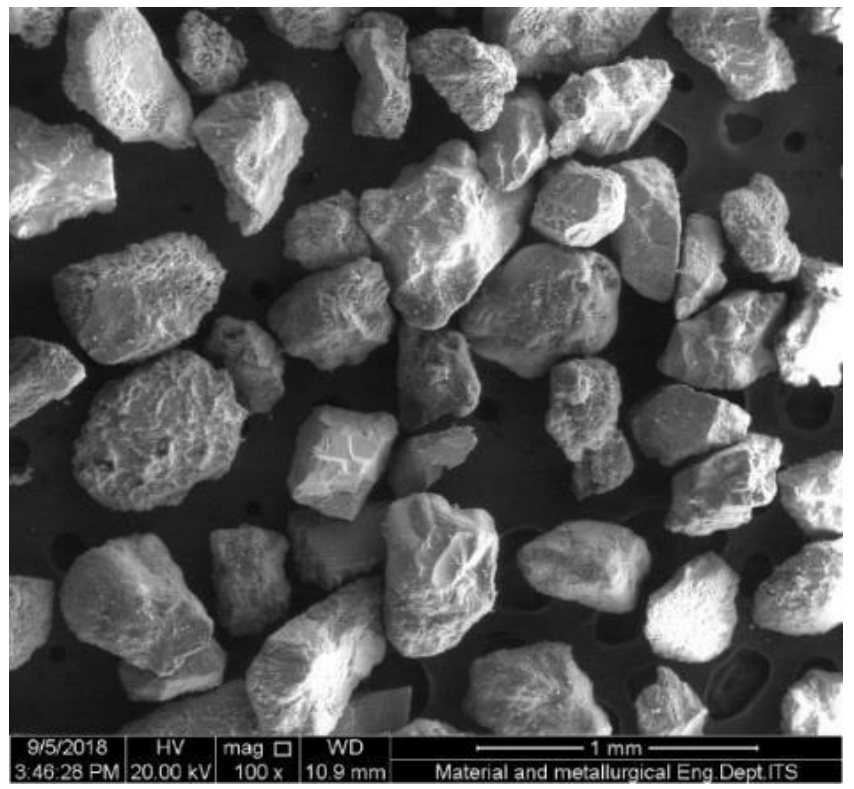

Gambar 10. Struktur mikro untuk sampel pertama

(Gambar dengan perbesaran 100x)

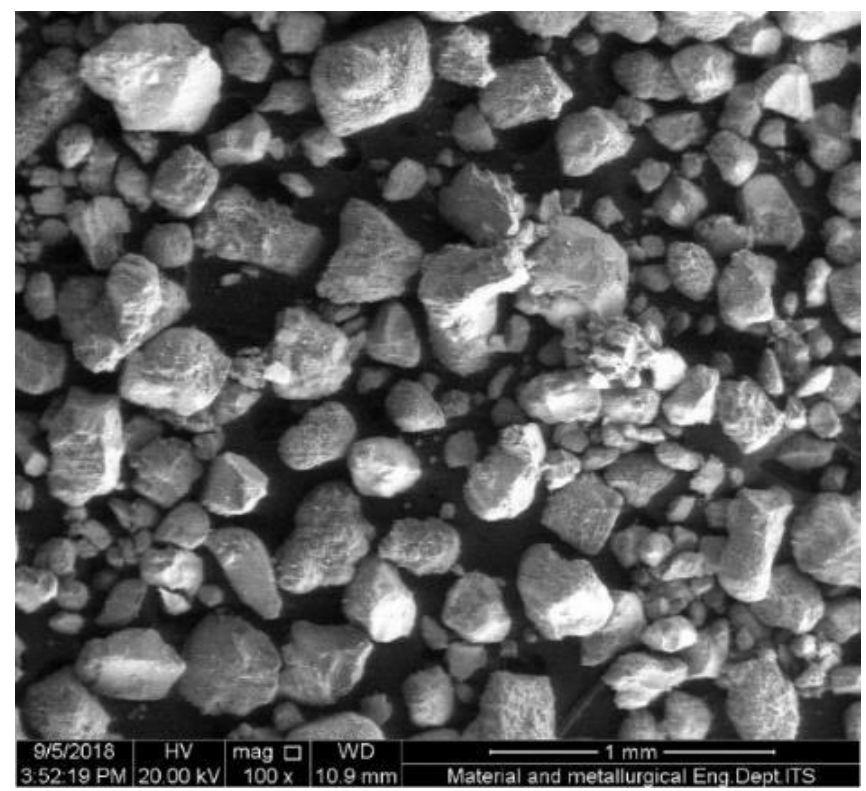

Gambar 11. Struktur mikro untuk sampel kedua

(Gambar dengan perbesaran 100x)

\section{KESIMPULAN}

Pasir yang diambil di dua tempat berbeda di sekitar sungai Brantas ternyata mengandung Kalsium Aluminium Silikat $\left(\mathrm{Al}_{2} \mathrm{CaO}_{8} \mathrm{Si}_{2}\right)$, Magnesium Vanadium Okxide $\left(\mathrm{Mg}_{0.966}\left(\mathrm{~V}_{1.64} \mathrm{Mg}_{0.36}\right) \mathrm{Mg}_{0.105} \mathrm{O}_{4}\right)$ dan Sodium Zinc Iron Phosphorus Oxide 
$\left(\mathrm{Na}\left(\mathrm{Zn} 0,8 \mathrm{Fe}_{0,2}\right) \mathrm{PO}_{4}\right)$ dan sedikit magnetit $\left(\mathrm{Fe}_{3} \mathrm{O}_{4}\right)$.

Untuk penelitian selanjutnya diharapkan metode ekstraksi yang digunakan tidak hanya diulang sebanyak 5 kali, tetapi juga dapat dilanjutkan setelahnya dengan penggilingan untuk memperkecil ukuran partikel dan dilanjutkan dengan kopresipitasi untuk mendapatkan sampel yang memiliki kemurnian lebih tinggi dan mempunyai ukuran orde nano.

\section{DAFTAR PUSTAKA}

[1] Li J.H., Hong R.Y, Li H.Z., Ding J., and Zheng Y., Wei D.G. "Simple Synthesis and magnetic properties of $\mathrm{Fe} 3 \mathrm{O} 4 / \mathrm{BaSO} 4$ multi-core/shell particles", Journal of Materials Chemistry and Physics, vol. 113, 2008. pp. 140-144.

[2] Munasir, Triwikantoro, M. Zainuri dan Darminto. "XRD and XRF Tests on Mineral Materials (Rock and Sand) as Sources of Intelligent Materials (CaCO3 dan $\mathrm{SiO} 2)$ ". Jurnal Penelitian Fisika dan Aplikasinya (JPFA),Vol 2 No 1, Juni 2012

[3] L. K. Sholihah, "Synthesis and Characteristics of Nanoparticles Fe3O4 Derived From Iron Sand and Fe3O4 Commercial Material (Aldrich)". Tugas Akhir. Jurusan Fisika F-MIPA ITS. Surabaya. 2010.

[4] Y.B. Feng, T. Qiu, C. Y. Shen. "Absorbing Properties and Sructural Design of microwave Absorbers Based on Carbonyl Iron and Barium Ferrite", Journal of Magnetism and Magnetic Materials, 2007. pp. 8-13.

[5] ESDM Office of East Java Province: Mining in Numbers. http://esdm.jatimprov.go.id. September 2018. (Accessed: 24-Januari 2019).

[6] M. Yandi. The advantages of Lumajang sand are that mining companies are interested in it. https://beritagar.id. September 2018. (Accessed: 24-Januari 2019).

[7] D.T. Rahmawati. dkk. "Added Variations $\mathrm{Fe} 3 \mathrm{O} 4$ on Alloy Pani/Fe3O4 as Microwave Absorbing Material”. Jurnal Fisika. Vol. 4 Nomor 10 Tahun 2015, hal 1-5.

[8] A.P. Hadi: "Interphase Transformation Study on Nano Composites Fe3O4/Fe2O3". Thesis. Jurusan Fisika FMIPA ITS Surabaya. 2009.

[9] Sutrisno: "Quantitative Analysis for Corundum and Pericles Mixture with Micro Absorption Effect". Tesis. Jurusan Fisika FMIPA ITS Surabaya. 2006.

[10] S. Pratapa: X-ray Diffraction Lecture Materials. Jurusan Fisika FMIPA ITS. Surabaya. 2004.

[11] A.B. Prasetyo. "Making $\alpha-\mathrm{Fe} 2 \mathrm{O} 3$ from the Process of Primary Hematite Type Iron Ore for Lithium Battery Raw Materials". Majalah Metalurgi, Vol. 29.3.2014, ISSN 0126-3188. 2014. 79-190.

[12] S.D. Rosanti dan D. Puryanti. "Effect of Temperature on Particle Size Fe3o4 with PEG-2000 Template Using Coprecipitation Method". Jurnal Ilmu Fisika (JIF), Vol 7 No 1, Maret 2015. 